\title{
Coercive Pressures and Anti-Corruption Reporting: The Case of ASEAN Countries
}

\section{$\underline{\text { Abstract }}$}

This paper aims to investigate the extent of anti-corruption reporting by ASEAN companies and examine whether coercive factors influence the level of disclosure. The authors adopt indicators from the Global Reporting Initiative version 4.0 to measure the extent of anti-corruption disclosures in 117 companies' annual reports. Informed by a coercive isomorphism tenet drawn from the institutional theory, the authors propose that several institutional factors influence the extent of their voluntary disclosures. The findings reveal that a large degree of variability difference between the average levels of anti-corruption disclosure in Thailand (434 words) and the Philippines (149 words). The dependence on government tenders and foreign ownership are associated with the level of disclosure. Surprisingly, the United Nation Global Compact membership is not a significant determinant of anti-corruption reporting. This signifies that the membership in the international initiative does not correspond to individual company's commitment to disclose anti-corruption information. In spite of significant efforts undertaken by global organizations to combat corruption, the level of anti-corruption disclosure is significantly different among the four countries under study. The disclosure of sensitive information such as the confirmed incidences of corruption cases requires careful consideration by the top management as it is subjected to legal implications and reputational risks. Thus, impression management can complement the coercive pressure in explaining the level of anti-corruption reporting. This study is among the first studies which explores the association between coercive factors and the level of anti-corruption disclosure in ASEAN region. 
Keywords Anti-corruption, disclosure, ASEAN, coercive pressures

\section{Introduction}

The definition and scope of corporate social responsibility (CSR) nowadays has been shifted and developed from its traditional definition (Joseph et al., 2016). Traditionally, CSR only focuses on environmental protection, labour health and safety, local communities, and also aspects in relation to consumers. As aspects of anti-corruptions were included in the Global Reporting Initiative (GRI) reporting guideline in 2002 and in the $10^{\text {th }}$ principle of United Nations Global Compact ${ }^{1}(\mathrm{UNGC})$ in 2004, corruption then became an integral part of CSR Issues (Branco and Matos, 2016). While corruption issues have been integrated to CSR for more than one decade, research shows that, generally, anti-corruption disclosure practices across the globe is still underdeveloped (see Branco and Matos, 2016; Joseph et al., 2016; Islam et al., 2017), particularly if they are compared to other CSR aspect disclosure practices (Adeyeye, 2012).

Corruption has hazardous impacts and negative consequences to society (Barkemeyer et al., 2015). Corruption is known as one of social diseases that became the main problem in many countries (Zhang et al., 2016). In the public sector, corruption diverts resources from essential services such education and health care into the corrupt government officials (Hills et al., 2009). In the private sector, corruption "inhibits free markets and undermines the stability vital to succesful economies" while also enabling the flow of huge amounts of illegal money to certain corrupt people (Kowalczyk-Hoyer, 2012, p. 4). Corruption thus acts like sand in the wheels, causing inefficiency in companies' operations (Hanoteau and Vial, 2014). In other words, corruption can 
increase costs and uncertainty in firms' activities. Wei (2000) argues that corruption is like an additional (but illicit) tax to a company which, of course, will reduce the company's investments and, consequently, will reduce the firm's productivity. Such reduced investment may include decisions to decline new technology investments, and efficient resource allocations efficiently (Hess, 2009).

Actually, corporate transparency can be deemed as the first line strategy to combat corporate corruption (Errath et al., 2005). Trough extensive disclosures, for instance, a company is able to communicate their values and policies, including the company's policies regarding anti-corruption, and how they are translated into actions (Transparency International, 2014). Disclosures which are formalized in a shape of public reporting and linked to the accountability chain help companies to gain legitimacy as the public and other stakeholders are informed about the companies' commitment and real actions and they then continuously support companies' operations and efforts to fight against corruption (United Nations Global Compact, 2015). Such a support presents because of the public trust which has been built by extensive corporate disclosures (Hess and Dunfee, 2000). This phenomenon is supported by a study conducted by PricewaterhouseCooper International (2008) which shows that the presence of the anticorruption program and the disclosures of that program are very valuable companies' image.

In addition to the above, a study by Kimbro (2002) reveals that more transparent reporting signals lower corruption. It is documented in the literature that corruption in developing countries is much more severe than corruption in developed countries (Shan et al., 2015; Adeyeye, 2012; d'Agostino et al., 2016; Brusca et al., 2018). The main 
problem that demotivates anti-corruption action in developing and transitional countries mainly comes from the weak accountability, the poor development of the legal institution, the frequent violations of law, regulations, and principles, as well as the restriction of civil freedom and healthy political competitions (Myint, 2000; Shan et al., 2015). Therefore, anti-corruption strategies should be mainly (and perhaps much strongerly) developed in these countries.

A similar situation happens in the Association of Southeast Asian Nations (ASEAN) member countries. The majority of ASEAN member countries are emerging nations and are ranked in the bottom half of the Corruption Perception Index (CPI) developed by Transparency International, a well-known international anti-corruption, non government organization based in Gernmany (Livingasean, 2017; Krongkaew, 2015). This means that most ASEAN countries are the world's most corrupt nations (RaoNicholson et al., 2016). This is ironic given that ASEAN member countries have had a formal agreement and commitment through a signed Memorandum of Understandig (MoU) to fight against corruption since 2004 (Jiangyu, 2012). The corruption phenomenon in the ASEAN region also contradicts the spirit of the current economic regional integration among ASEAN member countries, which is termed as ASEAN Economic Community (AEC), in which there are free movements of goods, services, investment, free flow of capital, and skilled labour within ASEAN region for creating a more competitive business environment within the region and improving the economy of ASEAN member countries (ASEAN, 2008; 2013).

As companies are expected to contribute to the collective actions against corruption and contribute to implementation of AEC (ASEAN, 2013; United Nations 
Global Compact, 2015), there are potential pressures from various powerful stakeholder groups such as the governments of ASEAN member countries which press companies to transparently communicate their commitments, policies, and actions regarding anticorruption efforts. To gain legitimacy and to be sustainable, companies operating in the ASEAN region needs to respond to those pressures. It is therefore considered important in this paper to examine anti-corruption disclosure practices in the ASEAN region and possible powerful stakeholders' pressures which press companies operating in that region to transparently communicate anti-corruption information.

This study brings at least two major contributions to the literature. Firstly, this study examines anti-corruption disclosures, a specific subset of CSR reporting which has gained growing attention in the social accounting literature recently (see for example Blanc et al., 2017; Islam et al., 2017) but the number of published papers on this specific disclosure practices is still considered small (Issa and Alleyne, 2018). The growing interest in anti-corruption reporting highlights the importance of this CSR subset in the accounting arena. Anti-corruption disclosure itself reflects the role of accounting in combating corruption. Secondly, this study examines anti-corruption disclosure practices in the ASEAN region, one of the most corrupt regions in the world based on Transparency International's report (Transparency International, 2016). To date, most studies on accounting practices in the ASEAN region focus on general financial accounting practices (e.g. Marzuki and Wahab, 2018) and a whole set of CSR disclosures (Arena et al., 2018). A study on anti-corruption reporting in the ASEAN region has actually been done by Joseph et al. (2016) but it focuses only on two countries, which are Indonesia and Malaysia. Moreover, Joseph et al. (2016)'s study does not investigate the 
potential factors explaining the disclosure practices. The current paper offers more comprehensive insights by investigating anti-corruption reporting in four ASEAN member countries (Indonesia, Thailand, Myanmar, Philippines) and the possible determinants of that reporting using the coercive isomorphism tenet.

\section{Literature review and theoretical framework}

To date, there has been a thin but growing literature about anti-corruption disclosure practices as an intergral part of CSR reporting. These studies have looked at anticorruption disclosure practices across geographic jurisdictions. Some studies focus on disclosure practices in one country and some other studies look at disclosure practices in multiple countries. Past studies examining anti-corruption disclosure practices in one specific nation include Islam et al. (2015), Branco and Matos (2016), D'onza et al. (2017), and Islam et al. (2017). Islam et al. (2015) examine anti-bribery reporting practices, a subset of anti-corruption disclosure, of two Chinese telecommunication companies. Branco and Matos (2016) investigate anti-corruption disclosure practices of 39 Poruguese firms. D'onza et al. (2017) examine the characteristic of anti-corruption disclosures of 120 Italian local governments. Islam et al. (2017) analyze anti-corruption disclosures of 20 largest Australian overseas aid not-for-profit organizations. There is a study by Gunawan and Joseph (2017) in Indonesia but is focuses on the activities of anticorruption, not reporting. In Gunawan and Joseph (2017)'s study, a focus group with respondents representing 10 Indonesian CSR best practice companies was undertaken to exlpore these companies' anti-corruption practices. 
Prior studies examining anti-corruption reporting in multiple countries include Barkemeyer et al. (2015), Healy and Serafeim (2016), Joseph et al. (2016), Blanc et al. (2017), Issa and Alleyne (2018) and Islam et al. (2018). Barkemeyer et al. (2015) examine anti-corruption dislclosures in 933 Global Reporting Initiative (GRI) corporate sustainability reports from 30 countries. Among these countries, there is only one ASEAN member country, which is the Philippines. Helay and Serafeim (2015) analyze whether 480 companies' anti-corruption disclosure from 32 countries reflect companies' real efforts to combat corruption. Among the country origins of the sample companies, there are three ASEAN member countries, which are Thailand, Singapore, and Malaysia. Joseph et al. (2016) examines the level of anti-corruption disclosure in annual reports of 24 Malaysian and 34 Indonesian CSR best practice companies. Malaysia and Indonesia are ASEAN member countries. Blanc et al. (2017) investigate anti-corruption disclosure by 105 biggest multinational companies whose headquarters are located in 23 different nations. None of these nations, however, is an ASEAN member country. Issa and Alleyne (2018) determine the level of anti-corruption disclosure in the sustainability reports of 66 Gulf Cooperation Council (GCC) companies in Saudi Arabia, Oman, Kuwait, Bahrain, UAE, and Qatar. Again, none of these countries is an ASEAN member nation. Islam et al. (2018) also examine disclosure practices outside the ASEAN region as they focus their research on anti-bribery disclosure practices of two European-based global telecommunication companies (French-based Alcatel-Lucent and German-based Siemens AG). It can be noted from the outline of these past studies that, while there are several multiple country studies which include several ASEAN member countries in their examinations, there are no past studies which exclusively analyze ASEAN companies. 
In terms of research methods used, prior anti-corruption disclosure studies can be classified into two main types of analyses - descriptive studies which generally show low disclosure levels (Joseph et al., 2016; Islam et al., 2017; Issa and Alleyne, 2018) and examinations of factors explaining the variability of disclosures (Barkemeyer et al., 2015; Islam et al., 2015; Branco and Matos, 2016; Healy and Serafeim, 2016; Blanc et al., 2017; D’onza et al., 2017; Islam et al., 2018). Interestingly, most of the descriptive-based studies use coercive isomorphism (Joseph et al., 2016; Issa and Alleyne, 2018) whereas most of the inferential-based studies employ legitimacy theory, either as a specifically individual framework (Branco and Matos, 2016; Blanc et al., 2017) or as a joint framework with other theories such as agency theory (D'onza et al., 2017) and media agenda setting theory (Islam et al., 2018). In fact, it is recommended in the literature that regulators' pressures on companies to disclose anti-corruption actions need to be examined. (see D'onza et al., 2017). Arguably, such an examination can only be undertaken under the umbrella of coercive isomorphism, a specific subset of institutional theory. This is because this specific tenet reflects pressures from powerful stakeholder groups, including regulators (DiMaggio and Powell, 1983; Cahaya et al., 2015; MartínezFerrero and García-Sánchez, 2017). To fill the existing literature gaps, this paper exlcusively examine anti-corruption reporting practices in the ASEAN region, one of the most corrupt regions in the world (Rao-Nicholson et al., 2016), by looking at both the extent and the determinants of the variability of that extent within the framework of coervice isomorphism so that potential pressures from powerful stakeholder groups, including regulators, can be captured. 
Institutional theory explains a situation in which an organization is insitutionally pressed to undertake particular activities, including anti-corruption disclosure practices (DiMaggio and Powell, 1983; Deegan and Unerman, 2011; Issa and Alleyne, 2018). Institutional theory is considered suitable for this study because it provides the complementary perspectives of stakeholder and legitimacy theory regarding voluntary disclosures (Deegan and Unerman, 2011; Deegan, 2014). As stated by Deegan and Unerman (2011) the similariy between institutional theory and legitimacy theory relies on the understanding how an organization adapts as a response to social and institutional pressures to meet social norms and values. Institutional theory itself is a branch of legitimacy theory (Perera, 2007; Cahaya et al., 2016; Cahaya et al., 2017). The similarity between institutional theory and stakeholder theory, on the other hand, relies on the managerial branch of stakeholder theory which explains that an organization uses voluntary disclosures to address economic and ethical values and concerns of influential stakeholders to whom the organization depend on (Deegan and Unerman, 2011). Due to such a comprehensive explanation, institutional theory is considered capable to to provide a richer analysis for a CSR accounting study (see Deegan, 2017).

Institutional theory has two branches - decoupling and isomorphism (Amran and Haniffa, 2011; Deegan, 2017). Decoupling explains a situation in which an organization's actual practices differ from its disclosures (Meyer and Rowan, 1977). Isomorphism, which is more popular in CSR accounting research, explains a situatin in which an organization is institutionally pressed by three ismorphic forces, which are coercive, mimetic, and normative pressures, to undertake particular practices such as disclosure practices (Dillard et al., 2004). Coercive isomorphism reflects pressures from influential 
stakeholders and thus this tenet is the one which is considered similar to managerial stakeholder theory (DiMaggio and Powell, 1983; Deegan, 2014). Mimetic isomorphism reflects a situation in which an organization copies other organizations' practices which usually operate in the same industry (Gray et al., 2010). Normative isomorphism reflects pressures from groups of norms (DiMaggio and Powell, 1983). As explained previously in this section, coervice isomorphism is the institutional theory subset which is chosen to be employed as the underlying theoretical framework of the current study.

Coercive isomorphism is the most widely employed subset of institutional theory in CSR accounting research (see for example Othman et al., 2011; Joseph et al., 2014; Cahaya et al., 2015; Cahaya et al., 2016; Joseph et al., 2016; Issa and Alleyne, 2018; Joseph et al., 2019). Coercive isomorphism involves formal and informal pressures exerted by other organizations which a particular organizations is dependent on (Martínez-Ferrero and García-Sánchez, 2017). More specifically, as explained by Amran and Haniffa (2011), the form of coercive pressures can include persuasions or invitations to join specific initiatives, political influences, enforced law, and also public pressure at large. Powerful institutions possibly press an organization to adopt specific practices can include customers, suppliers, competitors, governments, certifications body, and politically powerful stakeholders such as political parties (Deegan and Unerman, 2011). When there are pressures from these stakeholder groups, an organization needs to respond to gain legitimacy (DiMaggio and Powell, 1983; Wijethilake et al., 2017). Through such legitimacy, the organization's operations can be sustailanble.

While coercive isomorphism is similar to managerial stakeholder theory in terms of key-stakeholder focused management, there is a main difference between the two 
theories. Within the framework of coercive isomorphism, an organization discloses information as a response to pressures from influential stakeholders whereas, within the framework of managerial stakeholder theory, an organization actively identifies who their influential stakeholders are, what these stakeholders' expect companies to perform and disclose, and finally the organization attempts to perform the activities demanded by the influential stakeholders and discloses those activities (Deegan, 2014). To respond to prior researchers' recommendation to examine regulators' pressures on companies to communicate their anti-corruption actions (see D'onza et al., 2017), coervice isomorphism is considered more appropiate to be adopted in this study than managerial stakeholder theory. This is because regulators tend to reflect pressures through law enforcement or official campaigns (see DiMaggio and Powell, 1983). With or without a stakeholder indentification process, regulators are clearly powerful and influential to organizations. To further contribute to the existing literature, this study examines not only pressures from regulators but also pressures form other possible coercive sources. The explanation for the possible impacts of these examined coervice pressures on anticorruption reporting is presented in the following hyptoheses develpoment section.

\section{Hypotheses development}

This paper examines five key coervice variables potentially influencing the extent of anticorruption disclosure in the ASEAN region. These variables are government ownership, dependence on government tenders, foreign ownership, international operations, and the United Nations Global Compact (UNGC) membership. The following hypotheses 
development explains the logical associations between the five variables and the extent of anti-corruption reporting through the lens of coercive isomorphism.

\subsection{Government ownership}

Governments of ASEAN member countries actually have commitments to combat corruption and articulate these commitment in their countries' regulations although, in fact, corruption occurs frequently in this region. In Indonesia, for instance, there are a lot of regulations to prevent and combat corruption (Gunawan and Joseph, 2017). In this regulated condition, the governments potentially push companies to obey anti-corruption regulations and disclose their anti-corruption ations. Such a coercive pressure is particulary doable to entities whose capital stock structures are dominated by governments' shares. Government-owned companies themselves tend to be politically sensitive because their activities are more visible in front of the public eyes and there is a higher expectation for such firms to be conscious of their public duties (Muttakin and Subramaniam, 2015), in line with the coercive isomorphism tenet. A positively significant association between government ownership and the extent of CSR-related disclosures is well documented in the literature (e.g. Amran and Devi, 2008; Othman et al., 2011; Cahaya et al., 2012; Muttakin and Subramaniam, 2015; Branco and Matos, 2016). As such, this study proposes the following directional hypothesis:

H1. There is a positive relationship between government ownership and the extent of anti-corruption disclosure 


\section{2 Dependence on government tenders}

A company's dependence on government tenders reflects that the company's revenue is mostly from the government through projects (Amran and Devi, 2008). A tender phenomenon is usual for a government agency as it may not have sufficient internal resources to provide public services or build public facilities and therefore it outsource some projects to the pivate sector through tenders. It is not easy to win the tender as a company must compete with other companies which offer competitive prices and various qualities of product or services. A company's reputation may also be used as a basis for a government agency to decide the company which will win the tender. When the government is considered as a signicant purchaser through a tender, a company needs to maintain a good relationship with it by meeting the government's demands and expectations (Amran and Haniffa, 2011). This company is therefore potentially institutionalized by the government's aspirations (DiMaggio and Powell, 1983). In such a situation, the government definitely has a coervice power to press the company to undertake particular practices, including anti-corruption disclosure practices, as it may have anti-corruption agenda. If the company does not respond to this coercive pressure, its future project engagement with the government may be terminated (Amran and Haniffa, 2011; Deegan and Unerman, 2011). A positive association between companies' dependence on government tenders and CSR disclosure practices is found in Amran and Devi (2008) and Amran and Haniffa (2011). Accordingly, the following directional hypothesis is predicted:

H2. There is a positive relationship between dependence on government tenders and the extent of anti-corruption disclosure 


\subsection{Foreign Ownership}

Foreign ownership usually reflects srong influences on foreign business practices and a broader separation of ownership as well as management due to geographic distance between a company and its shareholders (Haniffa and Cooke, 2005; Oh et al., 2011; Jeon et al., 2011; Muttakin and Subramaniam, 2015). According to Haniffa and Cooke (2005), foreign shareholders tend to demand a high level of corporate disclosures because of the geographical separation. A foreign shareholder who usually comes from a developed country is likely to be more concerned with the company's global accountability, particulary how the company attempts to meet the global community's expectations in relation to sustainable business practices, including anti-corruption practices and reporting. This is where foreign shareholders' coercive pressure can come into play. Foreign shareholders can push companies to report anti-corruption activities and, by responding to this pressure, the companies may obtain continuous supports and legitimacy from this stakeholder group through capital inflows (see DiMaggio and Powel, 1983; Deegan and Unerman, 2011). A positive association between foreign ownership and disclosure practices is documented in some prior studies (Haniffa and Cooke, 2005; Khan et al., 2013; Muttakin and Subramaniam, 2015). A directional hypothesis is therefore proposed as follows:

H3. There is a positive relationship between foreign ownership and the extent of anti-corruption disclosure 


\section{4 International operations}

Companies may have business dealings with foreign stakeholders in today's global business enivornment, particulary when they operate internationally (see Appiah-Adu et al., 2016). When a company does have such an operation, coercive pressures from international stakeholders such as international regulations potentially present. (see Epstein and Buhovac, 2014). An overseas branch office, for example, undertakes anticorruption practices to comply with the regulations in the nation in which it operates. This CSR practice is potentially disclosed by the company through, for instance, an integrated reporting system to show its responses to the global coervice pressures regarding anti-corrpution programs so that penalties can be avoided (see Cahaya et al., 2017). Importantly, as a result of this diclosure, the company can gain its legitimacy to better survive in an international arena (Higgins and Larrinaga, 2014). In the literature, it is frequently documented that companies operating internationally disclose more CSR information (see for example Cahaya et al., 2012; Cahaya et al., 2017). The following hypothesis is thus proposed:

H4. There is a positive relationship between international operations and the extent of anti-corruption disclosure

\subsection{UNGC signatories}

A company's membership of a particular association or coalition potentially results in coercive pressure pressing the company to undertake particular practices. This includes a company's membership of UNGC whose principles include anti-corruption engagement. 
There are also some requirements to be met when a company wants to be the member. If the company does not respond to coercive pressures from the coalition or the association, the membership will usually be terminated. Past studies document the significantly positive impact of UNGC signatories on anti-corruption disclosure practices (Transparency International, 2009; Branco and Matos, 2016). A directional hypothesis is thus predicted as follows:

H5. There is a positive relationship between UNGC membership and the extent of anti-corruption disclosure

\subsection{Control variables}

In addition to the hypothesized independent variables and in line with previous studies (e.g. Kent and Zunker, 2013; Blanc et al., 2017; Cahaya and Hervina, 2019), this study employs industry type and company size as control variables. This is because these variables may influence anti-corruption disclosure practices. Companies operating in some industries possibly disclose more anti-corruption information as they deal with asset procurement and therefore face a higher corruption risk (Healy and Serafeim, 2016). Bigger companies potentially disclose more information because they have greater visibility (Hackston and Milne, 1996; Brammer and Pavelin, 2006; Blanc et al., 2017).

\section{Research methodology}


In line with most previous anti-corruption disclosure studies (e.g. Healy and Serafeim, 2016; Blanc et al., 2017; Issa and Alleyne, 2018), this paper uses Transparency International's corruption perception index (CPI) to determine the ASEAN member countries to be examined. Based on Transparency International's 2016 CPI index, four countries scored in the middle ranks among ASEAN member nations are chosen to be investigated. These selected countries are Indonesia, the Philippines, Thailand, and Vietnam, which are ranked $90^{\text {th }}, 101^{\text {st }}, 101^{\text {st }}$, and $113^{\text {th }}$ respectively (Transparency International, 2016). The main reason for choosing the middle-ranked ASEAN countries is that these countries arguably have similar corruption characteristics within the region. Similar coervice pressures and environments regarding anti-corruption efforts are therefore expected to occur within these nations.

Consistent with a multiple country anti-corruption disclosure study by Barkemeyer et al. (2015), this paper selects companies from the four ASEAN countries which adopt Global Reporting Initiative (GRI) guideline as the benchmark of their yearending 2016 CSR disclosures. This is because GRI guideline is the most widely used sustainability guideline in the world and has captured the latest relevant sustainability issues based on interviews with various stakeholders across the globe (Epstein and Buhovac, 2014; Shabana et al., 2017; Garcia-Sanchez et al., 2016). This guideline is therefore considered as the international de facto sustainability disclosure standard (de Villiers and Marques, 2016).

A list of companies operating in Indonesia, the Philippines, Thailand, and Vietnam and using GRI as the benchmark of their disclosures were obtained from the GRI database (http://database.globalreporting.org/search/). Further criteria were then 
applied to select the final sample companies. These criteria include whether or not a company used G4 version, the GRI version which is relevant to 2016 reporting and was launched in 2013 (Global Reporting Initiative, 2013), and whether or not a company's annual report, sustainability report, or integrated report in the GRI database was presented in English. In the database, it was found that there were 168 companies using G4 version for their 2016 reports. Among these 168 companies, there were only 117 companies presenting their reports in English. The final number of sample companies in this study is therefore 117. Data for the anti-corruption disclosure were collected from these 117 sample companies' reports, consisting of 32 annual reports, 79 sustainability reports, and 6 integrated reports, for the 2016 financial year. Website disclosures are not examined in this study as this study focuses on companies' disclosures for a particular reporting year, which is certainly reflected in annual report, sustainability report, or integrated report document. Table I presents the number of sample companies in each examined country.

\section{[Take in Table I]}

The dependent variable in this study, which is the level of anti-corruption disclosure, is measured by using content analysis. This is consistent with most previous CSR disclosure studies. Content analysis is "A technique for gathering data that consists of codifying qualitative information in anecdotal and literary form, into categories in order to derive quantitative scales of varying levels of complexity" (Abbott and Monsen, 1979, p. 504). Because a quantitative scale can be derived, the disclosure level can be treated as a 
continuous variable when it is measured by this approach. To employ this measurement approach, a researcher needs to determine a set of rules of 'what' and 'how' to code, measure, and record the documents (Milne and Adler, 1999). A unit of analysis is therefore needed for coding, measuring, and recording the disclosures examined in this study.

Previous studies employing content analysis use various units of analysis. These encompass length of narrative disclosures, presence of certain themes, number of sentences, number of items, number of issues, number of pages, number of lines, and number of words (Baker and Naser, 2000; Belal, 2001; Newson and Deegan, 2002; Vuontisjärvi, 2006; Maali et al., 2006; Mirfazli, 2008). While there is a debate in the literature as to the most appropriate unit of content analysis for measuring the extent of disclosure (see Guthrie and Abeysekera, 2006; Amran and Devi, 2008), a study by Smith et al. (2005) does not show any statistically different results when different units of analysis are used. Accordingly, in line with previous studies done by Gao et al. (2005) and Rao and Tilt (2016), this study employs number of words as the unit of analysis. Word counting is considered more practical, more controllable, and easily categorized (Gao et al., 2005; Haniffa and Cooke, 2005).

In a word counting approach, each sample company's annual report and sustainability report are carefully read to find any information which is dedicated to anticorruption themes listed on the disclosure checklist. For the purpose of such a measurement, G4 anti-corruption aspect, which consists of three indicators, is adopted as the disclosure checklist. To ensure that all anti-corruption issues are captured, the three G4 anti-corruption indicators are broken down into eleven subparts. Consistent with the 
technique used by Rao and Tilt (2016), any information which is dedicated to the three G4 anti-corruption indicators and their subparts is pasted to a Microsoft Word document. The number of words for each sample company's disclosure can then be calculated. Details of G4 anti-corruption indicators and their subparts used as the disclosure cheklist in this study are presented in Appendix.

The independent and control variables are mostly measured using the measurement approaches employed in past studies (Amran and Devi, 2008; Amran and Haniffa, 2011; Chiu and Wang, 2015; Branco and Matos, 2016; Cahaya et al., 2017; Cahaya and Hervina, 2019). With respect to industry type, this study uses a high-low corruption risk categorization based on Transparency International Bribe Payers Index. High-risk industries consist of agriculture, light manufacturing, civilian aerospace, information technology, banking and finance, forestry, consumer services, telecommunication, transportation and storage, arms, defense, and military, and fisheries whereas low-risk industries encompass heavy manufacturing, pharmaceutical and healthcare, power generation and transmission, mining, oil and gas, real estate, property, legal and business services, utilities, and public work contract and construction (Hardoon and Heinrich, 2011). The measurement approaches for the independent and control variables are presented in Table II. The quantitative data are statistically analyzed using descriptive statistics and multiple regression to determine the extent of anti-corruption disclosure and the determinants of that extent respectively.

\section{[Take in Table II]}




\section{Statistical results}

The results of the descriptive statistics for the independent and control variables are displayed in Table III. A total of 39 percent of sample companies are "privatized" government-owned companies whereas the other 61 percent are fully privately-owned companies. 73 percent of sample companies rely on major government tenders. A total of 79 percent of sample companies do have foreign ownerships in their share ownership structures. Most of the sample companies (81 percent) operate internationally. In relation to UNGC membership, only 8 percent of sample companies do have this membership. 44 percent of sample companies operate in high corruption risk industries. Finally, the descriptive statistics shows that total assets range widely from about 8 million US Dollars to around 339,703 million US Dollars with a mean of approximately 13,431 million US Dollars.

\section{[Take in Table III]}

The descriptive statistics of anti-corruption disclosure for the sample companies across the examined four ASEAN member countries is presented in Table IV. It can be seen from Table IV that the mean of anti-corruption disclosure level for all 117 sample companies is approximately 310 words. The highest dislcosure level is 986 words whereas the lowest level is 14 words. Table IV further shows that the highest average level of anti-corruption disclosure is in Thailand (about 434 words) while the lowest average level of anti-corruption disclosure is in the Philippines (around 149 words). The finding regarding the considerable difference between the average levels of anti- 
corruption disclosure in Thailand and the Philippines implies an interesting phenomenon that needs to bu further explored. From the perspective of Transparency International corruption rating, these two countries have a similar number of corruption cases. This is because their corruption ranks are the same, which is 101. In fact, however, there can be a different anti-corruption story in these two countries. In Thailand, companies appear to have a sronger commitment to combat corruption as evidenced by a number of meetings, joint programs, and collective actions agains corruption among Thai companies' senior officers (see Center for International Private Enterprise, 2013). In contrast, in the Philippines, companies seem to face a higher corruption risk, particularly when they deal with the public services (Business Anti-corruption Portal, 2017). In 2016, about half of business executives were asked for a bribe by someone in the Philippine government (Business Anti-corruption Portal, 2017). This might explain why Philippine companies tend to be silent on anti-corruption actions whereas Thai companies tend to actively disclose anti-corruption information.

\section{[Take in Table IV]}

Figure I shows the variation of disclosure levels across the three anti-corruption disclosure indicators by the 117 sample companies. It can be known from Figure I that communication and training on anti-corruption policies and procedures is the most disclosed indicator (11 companies, 94.87 percent). This result indicates that most sample companies actively attempt to prevent corruption by communicating their anti-corruption procedures and policies to relevant internal and external stakeholders such as employees 
and business partners ${ }^{2}$. By communicating such procedures and policies, the relevant stakeholders may know various important information such as how to report suspected corruption through the companies' whistleblowing systems and the consequences (penalties) of corruption. These stakeholders may then think twice before they do corruption and finally do not pursue their intention to corrupt. According to Halter et al. (2009), a well communicated anti-corruption policy can be used to reduce the level of corruption.

\section{[Take in Figure I]}

Confirmed incidents of corruption and actions taken, on the other hand, is the least disclosed indicator at $40.17 \%$. There are several possible explanations for this finding. Firstly, it involves the whistleblowing procedures. The whistle-blower is subjected to high personal risk in certain countries especially where is inadequately legal defence against firing, disgrace or at the same time physical violence. The employee or anyone in the organization will not whistle if there is a stringent requirement on reporting of information, denouncement and vilification laws, and ineffective scrutiny on claims made by whistle-blowers (Transparency International, 2018). This possibly hinders the reporting of corruption incidence and action plans to be undertaken. Moreover, in most cases, frauds were detected internally by the internal audit staff via internal control evaluation and review (KPMG, 2013), which is not intended to be reported publicly.

Secondly, the reporting of corruption incidences is closely related to the reputational risk. It appears that companies are very careful in disclosing the sensitive 
information to the public which is associated with the impression management theory. Meaning to say, companies may be bias in choosing the type of information to be used in the annual reports (Cho et al., 2010). In relation to this paper, communication and training on anti-corruption policies and procedures as the most disclosed indicator implies that the companies are highly committed to ensuring that corruptions risks are minimized. On the other hand, reporting of corruption incidences, if not appropriately communicated may be perceived negatively by shareholders. This is in line with a KPMG survey's finding in 2013, conducted on Malaysian public listed companies that revealed $47 \%$ of the respondents did not report the corruption incidences to the authority due to fear of negative publicity. Thus, the finding reveals that the companies are very careful in managing the public impression on the corruption issues in the annual reports.

Thirdly, there is no full compliance on the United Nation Global Compact principles. Due to the small number of companies that join the UNGC membership in this paper, there is a lack of awareness among the companies on the need to share the cases studies and success stories relating to corruption cases, which can be communicated via annual reports. The sharing of success stories is one of the elements suggested by the UN Global Compact when fighting corruption and implementing the 10th principle (UN Global Compact, n.d.). Thus, it can be concluded that companies which are members of the UN Global Compact are more coerced to disclose the incidence of corruption along side with the action plans to be undertaken.

As explained in the previous section, multiple regression is employed for statistically determining the explanatory factors of anti-corruption reporting. Accordingly, classical assumptions of multiple regression ${ }^{3}$, consisting of normality, 
multicollinearity, homoscedasticity, normality, and outliers (see Hair et al., 1998; Coakes, 2013; Ghozali, 2018), were checked. Initially, the normality assumption was not met. A closer analysis revealed that the residuals were moderately and positively skewed. According to Tabachnick and Fidell (2007), a square root transformation is the most suitable transformation method to be used when there is a moderately positive skewness in the residual data set. As such, data of all continuous variables in this study were then transformed by using a square root transformation. After this transformation, all of the assumptions were met. The results of the regression after the transformation are displayed in Table V.

\section{[Take in Table V]}

As shown in Table $\mathrm{V}$, the regression model is significant as its p-value, 0.027, is smaller than $5 \%$ significance level.. The value of adjusted R-square is 0.077 , suggesting that the variation of anti-corruption disclosure can be explained by the predictor variables in the model as much as almost $8 \%$. Government dependence and foreign ownership, which are hypothesized independent variables, are significant at 5\% and $1 \%$ significance levels respectively. As predicted, the coefficients of these variables are positive. This indicates that there are positive associations between anti-corruption disclosure practices and government dependence as well as foreign ownership. Hypotheses 2 and 3 are therefore accepted.

\section{Discussion and conclusion}


The results of this study shows that, on average, companies operating in Indonesia, the Phillipines, Thailand, and Vietnam disclose anti-corruption information in approximately 310 words. The highest average level of this disclosure is in Thailand (around 434 words) whereas the lowest average level is in the Philippines (about 149 words). It appears that companies in the Philippines are 'trapped' in a more corrupt environment (than the environment in Thailand) in which there are strong pressure from various stakeholders on the companies to corrupt or bribe, particularly when the companies deal with the public services. Among the three anti-corruption disclosure indicators, communication and training on anti-corruption policies and procedures is the most disclosed indicator while confirmed incidents of corruption and actions taken is the least disclosed indicator.

An important finding of this study is the positive significant impact of dependence on government tenders on the extent of anti-corruption disclosure. This finding is consistent with Amran and Devi (2008) and Amran and Haniffa (2011). It appears that the governments of Indonesia, the Phillipines, Thailand, and Vietnam utilize their coercive potentials to push companies to disclose anti-corruption information, particularly when those companies' main revenues are from governments' projects. In oder to survive and gain legitimacy, these companies do their best to respond to the coervice pressure by disclosing anti-corruption information. This result suggests that, in addition to the existing regulations about anti-corruption engagements, the governments may consider all of their business partners as potential fellows to collectively combat corruption. Thus, while formal coercive pressures from the governments through governance policies, acts, regulations, and their enforcements continue to present (see 
Joseph et al., 2016), informal coercive pressures trough a tender relationship will complement and even strengthen the efforts to reduce the level of corruption.

Another important finding is the positively significant influence of foreign ownership on anti-corruption disclosure practices. This result is in line with disclosure studies by Haniffa and Cooke (2005), Khan et al. (2013), and Muttakin and Subramaniam (2015), highlighting that the coervice pressure of foreign owners on companies to disclose anti-corruption information does exist. In particular, given that most of the sample companies do have foreign ownerships within their share ownership structures (see the descriptive results in Table III), the existing coercive pressure looks strong, causing companies to respond to this pressure. This finding highlights the importance of anti-corruption practices from the perspectives of global investors, implying that corruption has become a critical global bussiness communities' concerns (see Lehman and Morton, 2017; Issa and Alleyne, 2018). This result also implies that foreign investors having shares of companies in Indonesia, the Philippines, Thailand, and Vietnam are committed to sustainability, including anti-corruption activities. According to Epstein and Buhovac (2014), such investors can be classified as social investors.Government ownership is not a significant predictor of anti-corruption disclosure. This finding is in line with a number of past studies such as Cahaya et al. (2017). The governments of Indonesia, the Philippines, Thailand, and Vietnam might actively combat corruption but they focus more on government officials or civil servants working within the public sector agencies. This is because there are a lot of government officials in these countries who are involved in corruption and bribery (see Business Anti-corruption Portal, 2017; 
Salas, 2018). Thus, the governments do not have sufficient time and 'energy' to coercively push companies to disclose anti-corruption activities.

An interesting finding of this study is the insignificance of international operations given that global business communities currently consider anti-corruption as an important aspect companies need to address and disclose (see Lehman and Morton, 2017; Issa and Alleyne, 2018). This result is consistent with a disclosure study by Hanifa and Cahaya (2016). A possible explanation for this insignificant finding is that foreign stakeholders do not have 'face-to-face' interactions with sample companies' top management so that the top management do not respond to those stakeholders' coercive pressure. The top management may focus more on responding to the coercive pressures from their foreign owners who have a clearly legal power to push companies to undertake particular practices, including anti-corruption disclosure practices, through their share ownerships.

UNGC membership is not a significant determinant of anti-corruption reporting. This is consistent with Barkemeyer, Preuss, and Lee (2015). This insignificant finding might be explained by the descritpive statistics figure showing that only $8 \%$ of the sample companies are members of UNGC (see again Table III). Thee eight percent companies, seven companies are based in Thailand, one company is a based in the Philippines, and one themselves are dominated by Thai companies. Only two companies are based outside Thailad, which are Land Bank of the Philippines (the Philippine) and XL Axiata (Indonesia). This implies that coercive pressure does exist but is not strong enough to press companies in the four ASEAN member countries to disclose anti-corruption information. 
None of the control variables is significant. The result regarding industry type is in line with a disclosure study by Cahaya and Hervina (2019) and the finding in relation to company size is consistent with Blanc et al. (2017). While the high-low corruption risk industry categorization may reflect the potential presence of corruption within a specific industry, it is not associated with the quantity of anti-corruption disclosures. Bigger and smaller companies also disclose similar quantities of anti-corruption disclosures. High corruption risk companies and big companies may attempt not to 'talk' too much about their anti-corruption efforts due to the fact that they have problems with corruption. Low corruption risk companies and small companies, on the other hand, appear to be confident enough to disclose anti-corruption actions since they may have a smaller number of corruption incidents. These may result in similar levels of anti-corruption disclosures across different companies' industry types and across different company sizes.

Overall, it can be concluded that the variability of anti-corruption disclosure practices in Indonesia, the Phillipines, Thailand, and Vietnam is influenced by two coervice variables namely government dependence and foreign ownership in a positive direction. Anti-corruption reporting practices in these four ASEAN member countries are therefore partially explained by coervice isomorhism, a specific subset of institutional theory.

This study provides several implications. Firstly, the implication is relating to the pattern of anti-corruption plan adopted by each country. Quah (2009) evaluates three patterns of corruption control that have different features: 1) Anti-corruption laws without an anti-corruption agency; 2) Multiple anti-corruption agencies, and 3) Single anticorruption agency. In relation to this paper, the Philippines (the lowest discloser) has 
been identified as having the second type of corruption control, which is multiple anticorruption agencies. Meanwhile, Thailand (the highest discloser) has been identified as having the third pattern of corruption control, which is single anti-corruption agency. According to Quah (2009), the large number of anti-corruption agencies in the Philippines was due to the numerous changes in political leadership as those agencies were either created or abolished by the President. Among the agencies set up from 1950s to 2000s under different Presidents were Presidential Commission on Good Government, Presidential Committee on Public Ethics and Accountability, and Presidential Anti-Graft Commission. The changes of these agencies occured because of rising complaints from the public, complaining about the agencies' incompetence and resource shortages (e.g. manpower shortage and fund shortage). As stated by Quah (2009), these anti-corruption agencies' efforts to reduce corruption are deemed unsuccessful due to improper implementation of anti-corruption laws, rules and regulations, reflecting lack of coercive pressure.

In Thailand, the sole independent agency which is given an authority to combat corruption is the National Anti-Corruption Commission (NACC) (formerly named the National Counter Corruption Commission (NCCC)) (National Anti-Corruption Commission, 2014). NACC is responsible not to the Prime Minister but to the Senate. NACC has a full authority on management aspects, including staffing and budgeting. The members of NACC are nominated by the Senate and appointed by the King for a term of nine years. NACC has three functions, which are: 1) inspecting and verifying the declaration of the assets and liabilities submitted by the politicians and civil servants; 2) preventing corruption, and 3) taking disciplinary actions against corrupt politicians and 
civil servants (Quah, 2009). It appears that NACC has a strong coercive power to execute activities on combating corruption.

According to Quah (2009), the third pattern of corruption control (single anticorruption agency) is more effective than the second pattern of corruption control (multiple anti-corruption agencies). This is because a single anti-corruption agency is associated with the political will or commitment of their governments in curbing corruption. Using political will, a government makes law to authorize the anti-corruption agency to exercise the anti-corruption regulations objectively, indicating the coercive pressure. Simultaneously, in spite of this, the anti-corruption agency must be independent from political controls to allow allegations of corruption against political leaders and senior civil servants. The agency's sole effort on curbing corruption is an incredible gain as it is not disturbed by other urgencies. Thus, it is suggested from this paper that each ASEAN member country needs to focus on corruption prevention by implementing a single agency.

Secondly. other ASEAN member countries should refer to Singapore as a role model in combating corruption although this counrty is not examined in this study. This is because Singaporean citizens are better informed and educated in the government's anti-corruption strategy implementation (see Libres, 2016). In this manner, the people are very sensitive to corruption activities in both the public and private sectors. In Singapore, all laws and policies pertaining to anti-corruption are implemented completely. According to Khidhir (2019), Singapore maintains a high score among 180 countries in the 2018 Corruption Perceptions Index (CPI) released recently by Transparency International. In fact, strong enforcement efforts are only part of the 
Singaporean government's comprehensive and effective anti-corruption strategies. Singapore's reputation as a visible venue to conduct businesses is strengthened by a highlevel of its legislative framework, including corporate liability. The Corrupt Practices Investigation Bureau (CPIB), a Singaporean government agency which has the mandate to investigate into any acts of corruption in Singapore, has an extensive investigative power and has been widely perceived as independent and successful in achieving high conviction rates for corruption offences (Burke et. al., 2017).

The third implication of this study is related to the instilling culture of integrity by top management in organizations. As suggested by the ASEAN CSR Network (2017), there are several ways that can be implemented by top management to combat corruption in organizations. These include: 1) integrating anti-corruption values in the management's communications, decisions and actions, 2) identifying corruption risks which is embedded in companies' policies, 3) committing to anti-corruption policies regardless of the outcome of the implementation, 4) providing rewards and training for staff, and 5) making a strong whistleblowing policy.

Getting organizational culture right is essential for preventing and resisting corruption (IBAC, 2019). The culture must be first set by top management and followed by all members throughout the organization. Managers set up and inculcate the culture within their teams and organizations. At the same time, they have the chance to set the tone and standard from the outset. This will enable employees to understand their roles and responsibilities, and experience the sense of belonging in the organization. In developing a good culture, a robust integrated governance is required - a combination of policies and procedures and a true leadership. Specifically, a middle management has a 
particularly important role to play by bridging the gap between policymakers and employees working at the operational level. Processes and governance can be planned and managed once the identification of financial, reputational or technological risks have been identified. The governance should be a used as a foundation of anti-corruption and integrity culture. Therefore, staff as the human capital must be regularly trained to internalize the culture. At the same time, the polices and procedures must be updated and regularly reviewed from time to time (IBAC, 2019).

Fourthly, the implication of this study gives an impression that Thailand is trying very hard to improve its reputational risk and manage stakeholders' impressions. In short, both the private and public sectors in Thailand have been keen to improve compliance practices in enhancing the international community's view on Thailand's transparency levels and ensuring that investors will be better protected from the risk of bribery. This is due to the use of strong internal control measures by multinational companies operating in Thailand. The use of internal control measures by many multinational companies has been driven by other international regulations such as the US Foreign Corrupt Practices Act, the UK Bribery Act and other similar anti-corruption laws of the jurisdictions in which they may operate (Tungsuwan, 2017). Definitely, this practice influences other Thai companies to implement appropriate internal controls measures

Finally, the findings of this study suggest that there should be a strong collaboration among anti-corruption agencies in the ASEAN member countries. In spite of the existence of several anti-corruption initiatives, partnerships and exchanges within the region, challenges still exist as a result of the emerging corruption risks stemming from the increased regional integration in AEC. In addition to the establishment of AEC, 
strategic action plans and formal agreements are needed to further combat corruption in the region. Thus, more initiatives could be pushed among ASEAN leaders to put transparency and anti-corruption activities in their inter-regional ministerial agenda, enabling the promotion of greater transparency and the fight against corruption. This definitely could help ASEAN countries to attain smoother and more sustainable levels of political, economic, and socio-cultural integration. All anti-corruption agencies in this region can exchange ideas and information as well as learn from one another's best practises and experiences in fighting corruption.

There are several far-reaching consequences potentially experienced by ASEAN countries if corruption remains unresolved. Few ASEAN countries have faced acute deprivation for years and years, with millions of citizens leaving the countries to earn better livings in other countries (Satar, 2015). Such a condition reflects inequality in income. Inequality in income will continue to increase due to an improper regional economic integration which only benefits a few well-connected elites. Corruption is pricey and causes a great loss to a nation in terms of economic growth, trade, foreign investments, and the country's competitiveness which, in turn, results in overloading the government's expenditure, along with distorting the market mechanism and causing resource misallocations. Moreover, the corruption is the main stumbling block for a country to achieve sustainable development goals (SDGs). Curbing corruption including money laundering is very important for ASEAN to achieve its growth target and establish a sound investment environment as well as financial stability within the region.

As with all research, there are limitations associated with this study. Firstly, not all companies operating in Indonesia, the Phillipines, Thailand, and Vietnam found in the 
GRI database are examined. This is because some companies listed on the GRI database did not present their reports in English. Such a language barrier might prevent some important insights from being captured in this study. Secondly, there might be some subjectivity while doing the content analysis. According to the Writing Center of Colorado State University (2007), a conceptual content analysis can be considered to establish the "existence and frequency of concepts" in a text. This is most often represented by words or phrases. In this study, the word count relating to sample companies' corruption risk assessment is the example. However, "as a research method, content analysis is inherently subjective and presents a number of practical challenges" such as difficulties in selecting recording units, coding of repetitive message and subjective judgements (Steenkamp and Northcott, 2007, p. 20). To minimize subjectivity in this study, data were independently verified by two coders who have experiences in CSR reporting research.

Future multiple country anti-corruption disclosure studies should be undertaken by research teams whose members are the natives of the examined countries. Thus, language will not be a barrier if the examined reports are not presented in English. Future studies may also need to extend this research by constructing a more updated disclosure checklist based on other international guidelines relating to anti-corruption. At the same time, the validity of the disclosure instrument could be further improved by examining a few samples from ASEAN companies' annual reports to capture 'real disclosure' by the firms. Validation from practitioners and experienced scholars may also add credibility to the disclosure checklist. 


\section{Compliance with Ethical Standards}

\subsection{Funding}

The authors declare that they don't receive any research grants to fund this project.

\subsection{Ethical approval}

This article does not contain any studies with human participants or animals performed by any of the authors.

\subsection{Informed consent}

No human subjects were involved in this study.




\section{References}

Abbott, W. F., \& Monsen, R. J. (1979). On the measurement of corporate social responsibility: Self-reported disclosures as a method of measuring corporate social involvement. Academy of Management Journal, 22(3), 501-515.

Adeyeye, A. O. (2012). Corporate social responsibility of multinational corporations in developing countries: Perspectives on anti-corruption. Cambridge: Cambridge University Press.

Amran, A., \& Haniffa, R. (2011). Evidence in development of sustainability reporting: A case of a developing country. Business Strategy and the Environment, 20(3), 141156.

Amran, A., \& Devi, S. S. (2008). The impact of government and foreign affiliate influence on corporate social reporting: The case of Malaysia. Managerial Auditing Journal, 23(4), 386-404.

Appiah-Adu, K., Okpattah, B. K., \& Djokoto, J. G. (2016). Technology transfer, outsourcing, capability and performance: A comparison of foreign and local firms in Ghana. Technology in Society, 47, 31-39.

Arena, C., Liong, R., \& Vourvachis, P. (2018). Carrot or stick: CSR disclosures by Southeast Asian companies. Sustainability Accounting, Management and Policy Journal, 9(4), 422-454.

ASEAN. (2008). ASEAN economic community blueprint. http://www.asean.org/archive/5187-10.pdf. Accessed 18 May 2014.

ASEAN. (2013). ASEAN Comprehensive Investment Agreement (ACIA)-A Guidebook for Businesses and Investors. http://investasean.asean.org/index.php/ajax/exec ajax/file download/824/newsid/973 /asean-comprehensive-investment-agreement-a-guidebook-for-businesses-andinvestors.pdf. Accessed 27 February 2014.

ASEAN CSR Network. (2017). Governance: How is it connected to sustainability?, http://asean-csr-network.org/c/news-a-resources/csr-news-from-around-asean/1123acn-at-the-sid-conference-2017-the-sustainability-imperative. Accessed 23 October 2019.

Baker, A. and Naser, K. (2000). Empirical evidence on corporate social disclosure (CSD) practices in Jordan. International Journal of Commerce \& Management, 10( $3 / 4)$, 18-34.

Barkemeyer, R., Preuss, L., \& Lee, L. (2015). Corporate reporting on corruption: An international comparison. Accounting Forum, 39(4), 349-365.

Belal, A. R. (2001). A study of corporate social disclosure in Bangladesh. Managerial Auditing Journal, 16(5), 274-289.

Blanc, R., Islam, M. A., Patten, D. M., \& Branco, M. C. (2017). Corporate anti-corruption disclosure: An examination of the impact of media exposure and country-level press freedom. Accounting, Auditing \& Accountability Journal, 30(8), 1746-1770.

Brammer, S., \& Pavelin, S. (2006). Voluntary Environmental Disclosures by Large UK Companies. Journal of Business Finance \& Accounting, 33(7-8), 1168-1188.

Branco, M. C., \& Matos, D. (2016). The fight against corruption in Portugal: Evidence from sustainability reports. Journal of Financial Crime, 23(1), 132-142. 
Brusca, I., Rossi, F. M., \& Aversano, N. (2018). Accountability and Transparency to fight against corruption: An international comparative analysis. Journal of Comparative Policy Analysis: Research and Practice, 20(5), 486-504.

Burke, M., Kawai, W., \& Gargaro, D. (2017). Anti-corruption enforcement in the ASEAN region. https://globalinvestigationsreview.com/benchmarking/the-asia-pacificinvestigations-review-2018/1147518/anti-corruption-enforcement-in-the-aseanregion. Accessed 23 October 2019.

Business Anti-corruption Portal. (2017). The Philippines corruption report. https://www.business-anti-corruption.com/country-profiles/the-philippines// Accessed 7 February 2019.

Cahaya, F. R., \& Hervina, R. (2019). Do human rights issues matter? An empirical analysis of Indonesian companies' reporting. Social Responsibility Journal, 15(2), 226-243.

Cahaya, F. R., Porter, S., \& Tower, G. (2016). Coercive media pressures on Indonesian companies' labour communication. International Journal of Critical Accounting, $8(2), 95-117$.

Cahaya, F. R., Porter, S., Tower, G., \& Brown, A. (2015). The Indonesian Government's coercive pressure on labour disclosures: Conflicting interests or government ambivalence? Sustainability Accounting, Management and Policy Journal, 6(4), 475-497.

Cahaya, F. R., Porter, S., Tower, G., \& Brown, A. (2017). Coercive pressures on occupational health and safety disclosures. Journal of Accounting in Emerging Economies, 7(3), 318-336.

Cahaya, F. R., Porter, S. A., Tower, G., \& Brown, A. (2012). Indonesia's low concern for labor issues. Social Responsibility Journal, 8(1), 114-132.

Center for International Private Enterprise. (2013). Business shows clear commitment to fighting corruption in Thailand. https://www.cipe.org/blog/2013/02/01/businessshows-clear-commitment-to-fighting-corruption-in-thailand/. Accessed 7 February 2019.

Chiu, T. K., \& Wang, Y. H. (2015). Determinants of social disclosure quality in Taiwan: An application of stakeholder theory. Journal of Business Ethics, 129(2), 379-398.

Cho, C. H., Roberts, R. W., \& Patten, D. M. (2010). The language of US corporate environmental disclosure. Accounting, Organizations and Society, 35(4), 431-443.

Coakes, S. J. (2013). SPSS 20.0 for Windows: Analysis without anguish: Version 20 for Windows. Milton: John Wiley \& Sons Australia.

d'Agostino, G., Dunne, J. P., \& Pieroni, L. (2016). Corruption and growth in Africa. European Journal of Political Economy, 43, 71-88.

D’onza, G., Brotini, F., \& Zarone, V. (2017). Disclosure on measures to prevent corruption risks: A study of Italian local governments. International Journal of Public Administration, 40(7), 612-624.

de Villiers, C., \& Marques, A. (2016). Corporate social responsibility, country-level predispositions, and the consequences of choosing a level of disclosure. Accounting and Business Research, 46(2), 167-195.

Deegan, C. (2014). Financial accounting theory (4th ed.). North Ryde, NSW: McGrawHill Education Australia Pty Ltd. 
Deegan, C. (2017). Twenty five years of social and environmental accounting research within Critical Perspectives of Accounting: Hits, misses and ways forward. Critical Perspectives on Accounting, 43, 65-87.

Deegan, C., \& Unerman, J. (2011). Financial accounting theory (2nd European ed.). Berkshire: McGraw-Hill.

Dillard, J. F., Rigsby, J. T., \& Goodman, C. (2004). The making and remaking of organization context: Duality and the institutionalization process. Accounting, Auditing \& Accountability Journal, 17(4), 506-542.

DiMaggio, P. J., \& Powell, W. W. (1983). The iron cage revisited: Institutional isomorphism and collective rationality in organizational fields. American Sociology Review, 48(2), 146-160.

Epstein, M. J., \& Buhovac, A. R. (2014). Making sustainability work: Best practices in managing and measuring corporate social, environmental, and economic impacts (2nd ed.). Sheffield: Greenleaf Publishing Limited.

Errath, B., Brew, P., Moberg, J., Brooks, J., \& Cote-Freeman, S. (2005), Business against corruption - A framework for action. https://www.ingentaconnect.com/content/ungc/ungcr/2006/00000001/00000001/a rt00001. Accessed 24 January 2019.

Gao, S. S., Heravi, S., \& Xiao, J. Z. (2005). Determinants of corporate social and environmental reporting in Hong Kong: A research note. Accounting Forum, 29(2), 233-242.

García-Sánchez, I., Cuadrado-Ballesteros, B., \& Frias-Aceituno, J. (2016). Impact of the institutional macro context on the voluntary disclosure of CSR information. Long Range Planning, 49(1), 15-35.

Ghozali, I. (2018). Aplikasi analisis multivariete dengan program IBM SPSS 25 (9th ed.). Semarang: Badan Penerbit Undip.

Global Reporting Initiative. (2013). http://www.globalreporting.org. Accessed 7 August 2013.

Gray, R., Owen, D., \& Adams, C. (2010). Some theories for social accounting? A review essay and a tentative pedagogic categorisation of theorisations around social accounting. Advances in Environmental Management and Accounting, 4, 1-54.

Gunawan, J., \& Joseph, C. (2017). The Institutionalization of anti-corruption practices in Indonesian Companies. In D. Crowther and S. Seifi (eds.), Modern Organisational Governance (pp. 147-159). West Yorkshire: Emerald.

Guthrie, J., \& Abeysekera, I. (2006). Content analysis of social, environmental reporting: What is new? Journal of Human Resource Costing \& Accounting, 10(2), 114-126.

Hackston, D., \& Milne, M. J. (1996). Some determinants of social and environmental disclosures in New Zealand companies. Accounting, Auditing \& Accountability Journal, 9(1), 77-108.

Hair, J. F., Anderson, R. E., Tatham, R. L., \& Black, W.C. (1998). Multivariate data analysis (5th ed.). New Jersey: Prentice-Hall.

Halter, M. V., de Arruda, M. C. C., \& Halter, R. B. (2009). Transparency to reduce corruption? Journal of Business Ethics, 84(3), 373-385.

Hanifa, A., \& Cahaya, F. R. (2016). Ethical communication on society issues: A story from Indonesia. Journal of Global Responsibility, 7(1), 39-55. 
Haniffa, R. M., \& Cooke, T. E. (2005). The impact of culture and governance on corporate social reporting. Journal of Accounting and Public Policy, 24(5), 391-430.

Hardoon, D., \& Heinrich, F. (2011). Bribe payers index 2011. Berlin: Transparency International.

Healy, P. M., \& Serafeim, G. (2016). An analysis of firms' self-reported anticorruption efforts. Accounting Review, 91(2), 489-511.

Hess, D. (2009). Catalyzing corporate commitment to combating corruption. Journal of Business Ethics, 88(4), 781-790.

Hess, D., \& Dunfee, T. E. (2000). Fighting corruption: A principled approach: The C principles (combating corruption). Cornell International Law Journal, 33(3), 593626.

Higgins, C., \& Larrinaga, C. (2014). Sustainability reporting: Insights from institutional theory. In J. Bebbington, J. Unerman, and B. O'Dwyer (eds.), Sustainability Accounting and Accountability (pp. 273-285). New York: Routledge.

Hills, G., Fiske, L., \& Mahmud, A. (2009). Anti-corruption as Strategic CSR: A call to action for corporations. http://www.ethics.org/files/u5/Anti-corruptionFINAL.pdf. Accessed 20 January 2014.

IBAC. (2019). Tone from the top - getting the culture right to prevent corruption. https://www.ibac.vic.gov.au/publications-and-resources/ibac-insights/issue-20/tonefrom-the-top---getting-the-culture-right-to-prevent-corruption. Accessed 25 October 2019.

Islam, M. A., Dissanayake, T., Dellaportas, S., \& Haque, S. (2018). Anti-bribery disclosures: A response to networked governance. Accounting Forum, 42(1), 3-16.

Islam, M. A., Haque, S., Dissanayake, T., Leung, P., \& Handley, K. (2015). Corporate disclosure in relation to combating corporate bribery: A case study of two Chinese telecommunications companies. Australian Accounting Review, 25(3), 309-326.

Islam, M. A., Haque, S., \& Gilchrist, D. (2017). NFPOs and their anti-corruption disclosure practices. Public Money \& Management, 37(6), 443-450.

Jeon, J. Q., Lee, C., \& Moffett, C. M. (2011). Effects of foreign ownership on payout policy: Evidence from the Korean market. Journal of Financial Markets, 14(2), 344375.

Jiangyu, W. (2012). ASEAN struggles in anti-corruption fight. http://www.globaltimes.cn/content/726141.shtml. Accessed 23 January 2019.

Joseph, C., Gunawan, J., Madi, N., Janggu, T., Rahmat, M., \& Mohamed, N. (2019). Realising sustainable development goals via online integrity framework disclosure: Evidence from Malaysian and Indonesian local authorities. Journal of Cleaner Production, 215, 112-122.

Joseph, C., Gunawan, J., Sawani, Y., Rahmat, M., Noyem, J. A., \& Darus, F. (2016). A comparative study of anti-corruption practice disclosure among Malaysian and Indonesian Corporate Social Responsibility (CSR) best practice companies. Journal of Cleaner Production, 112(4), 2896-2906.

Joseph, C., Pilcher, R., \& Taplin, R. (2014). Malaysian local government internet sustainability reporting. Pacific Accounting Review, 26(1/2), 75-93.

Kent, P., \& Zunker, T. (2013). Attaining legitimacy by employee information in annual reports. Accounting, Auditing \& Accountability Journal, 26(7), 1072-1106. 
Khan, A., Muttakin, M. B., \& Siddiqui, J. (2013). Corporate governance and corporate social responsibility disclosures: Evidence from an emerging economy. Journal of Business Ethics, 114(2), 207-223.

Khidhir, S. (2019). Corruption: How is ASEAN performing? https://theaseanpost.com/article/corruption-how-asean-performing. Accessed 24 October 2019.

Kimbro, M. B. (2002). A cross-country empirical investigation of corruption and its relationship to economic, cultural, and monitoring institutions: An examination of the role of accounting and financial statements quality. Journal of Accounting, Auditing \& Finance, 17(4), 325-350.

Krongkaew, M. (2015). Transparency and Anti-Corruption Efforts in East Asia: An Observation. International Journal of East Asian Studies, 19(2), 71-94.

KPMG. (2013). KPMG Malaysia fraud, bribery and corruption survey 2013. https://assets.kpmg.com/content/dam/kpmg/pdf/2016/03/fraud-survey-report.pdf Accessed 10 March 2019.

Lehman, G., \& Morton, E. (2017). Accountability, corruption and social and environment accounting: Micro-political processes of change. Accounting Forum, 41(4), 281-288.

Libres, J. R. (2016). Comparative analysis on corruption perception in the Philippines, Singapore and Japan: Basis for anti-corruption strategy. 3rd International Teacher Education Student Conference (TEStCon), Cebu City.

Livingasean. (2017). 8 ASEAN countries fare badly on corruption index. http://livingasean.com/explore/8-asean-countries-fare-badly-corruption-index/

Accessed 24 January 2019.

Maali, B., Casson, P., \& Napier, C. (2006). Social reporting by Islamic banks. Abacus, 42(2), 266-289.

Martínez-Ferrero, J., \& García-Sánchez, I. (2017). Coercive, normative and mimetic isomorphism as determinants of the voluntary assurance of sustainability reports. International Business Review, 26(1), 102-118.

Marzuki, M. M., \& Wahab, E. A. A. (2018). International financial reporting standards and conservatism in the Association of Southeast Asian Nations countries: Evidence from Jurisdiction Corruption Index. Asian Review of Accounting, 26(4), 487-510.

Meyer, J. W., \& Rowan, B. (1977). Institutionalized organizations: Formal structure as myth and ceremony. American Journal of Sociology, 83(2), 340-363.

Milne, M. J., \& Adler, R. W. (1999). Exploring the reliability of social and environmental disclosures content analysis. Accounting, Auditing \& Accountability Journal, 12(2), 237-256.

Mirfazli, E. (2008). Evaluate corporate social responsibility disclosure at Annual Report Companies in multifarious group of industry members of Jakarta Stock Exchange (JSX), Indonesia. Social Responsibility Journal, 4(3), 388-406.

Muttakin, M. B., \& Subramaniam, N. (2015). Firm ownership and board characteristics: Do they matter for corporate social responsibility disclosure of Indian companies? Sustainability Accounting, Management and Policy Journal, 6(2), 138-165.

Myint, U. (2000). Corruption: Causes, consequences and cures. Asia Pacific Development Journal, 7(2), 33-58.

National Anti-Corruption Commission (2014). https://www.nacc.go.th/main.php?filename=index_en. Accessed 23 November 2019. 
Newson, M., \& Deegan, C. (2002). Global expectations and their association with corporate social disclosure practices in Australia, Singapore, and South Korea. The International Journal of Accounting, 37(2), 183-213.

Oh, W. Y., Chang, Y. K., \& Martynov, A. (2011). The effect of ownership structure on corporate social responsibility: Empirical evidence from Korea. Journal of Business Ethics, 104(2), 283-297.

Organisation for Economic Co-operation and Development. (2008). OECD guidelines for multinational enterprises. https://doi.org/10.1787/9789264060326-en. Accessed 22 April 2018.

Othman, S., Darus, F., \& Arshad, R. (2011). The influence of coercive isomorphism on corporate social responsibility reporting and reputation. Social Responsibility Journal, 7(1), 119-135.

Perera, H. (2007). The international and cultural aspects of social accounting. In R. Gray and J. Guthrie (eds.), Social Accounting, Mega Accounting and Beyond: A festschrift in Honour of M.R. Mathews (pp. 91-99). St. Andrews: CSEAR Publishing.

PricewaterhouseCoopers International. (2008). Confronting corruption: The business case for an effective anti-corruption programme. https://www.pwc.co.za/en/assets/pdf/pwc-confronting-corruption-08.pdf. Accessed 24 January 2019.

Quah, J. S. T. (2009). Combating corruption in the Asia-Pacific countries: What do we know and what needs to be done? International Public Management Review, 10(1), 5-33.

Rao-Nicholson, R., Salaber, J., \& Cao, T. H. (2016). Long-term performance of mergers and acquisitions in ASEAN countries. Research in International Business and Finance, 36, 373-387.

Rao, K., \& Tilt, C. (2016). Board diversity and CSR reporting: An Australian study. Meditari Accountancy Research, 24(2), 182-210.

Salas, A. (2018). Slow, imperfect progress across Asia Pacific. https://www.transparency.org/news/feature/slow imperfect progress across asia pacific. Accessed 5 March 2019.

Satar, A. (2015). Fighting graft should be on agenda at Asean summit. https://m.malaysiakini.com/letters/285614. Accessed 24 October 2019.

Shabana, K. M., Buchholtz, A. K., \& Carroll, A. B. (2017). The institutionalization of corporate social responsibility reporting. Business \& Society, 56(8), 1107-1135.

Shan, M., Chan, A. P. C., Le, Y., Xia, B., \& Hu, Y. (2015). Measuring corruption in public construction projects in China. Journal of Professional Issues in Engineering Education and Practice, 141(4), 1-11.

Smith, J. V. D. L., Adhikari, A., \& Tondkar, R.H. (2005). Exploring differences in social disclosures internationally: A stakeholder perspective. Journal of Accounting and Public Policy, 24(2), 123-151.

Steenkamp, N., \& Northcott, D. (2007). Content analysis in accounting research: The practical challenges. Australian Accounting Review, 17(3), 12-25.

Tabachnick, B. G. \& Fidell, L. S. (2007). Using multivariate statistics (5 ${ }^{\text {th }}$ ed. ). Boston: Allyn \& Bacon/Pearson Education. 
Transparency International. (2009). Transparency in reporting on anti-corruption: A report of corporate practices https://www.transparency.org/whatwedo/publication/transparency in reporting on anti_corruption_a report on_corporate_practice. Accessed 22 March 2019.

Transparency International. (2014). Transparency in corporate reporting: Assessing the world's largest companies. file:///C:/Users/226826B/Downloads/2014_TransparencyInCorporateReporting_T RAC EN.pdf. Accessed 24 January 2019.

Transparency International. (2016). Corruption perceptions index 2016. https://www.transparency.org/news/feature/corruption perceptions index 2016. Accessed 19 February 2018.

$\begin{array}{lll}\text { Transparency } & \text { International. } & \text { (2018). Whistleblowing. }\end{array}$ https://www.transparency.org/topic/detail/whistleblowing. Accessed 10 March 2019.

Tungsuwan, P. (2017). New developments in anti-corruption compliance in Thailand. Available from: https://www.bangkokpost.com/business/1343119/newdevelopments-in-anti-corruption-compliance-in-thailand. Accessed 23 October 2019.

United Nations Global Compact. (2015). A practical guide for collective actions against corruption. $\quad$ https://www.unglobalcompact.org/docs/issues doc/AntiCorruption/CollectiveActionExperiencesGlobal.pdf. Accessed 24 January 2019.

UN Global Compact. (n.d.). The ten principles of the UN Global Compact. https://www.unglobalcompact.org/what-is-gc/mission/principles/principle-10 Accessed 10 March 2019.

Vuontisjärvi, T. (2006). Corporate social reporting in the European context and human resource disclosures: An analysis of Finnish companies. Journal of Business Ethics, 69(4), 331-354.

Wei, S. (2000). How taxing is corruption on international investors? Review of Economics and Statistics, 82(1), 1-11.

Wijethilake, C., Munir, R., \& Appuhami, R. (2017). Strategic responses to institutional pressures for sustainability: The role of management control systems. Accounting, Auditing \& Accountability Journal, 30(8), 1677-1710.

Writing Center Colorado State University. (2007). Content analysis. http://www.writing.colostate.edu/references/research/content/pop2a.cfm Accessed 31 December 2007.

Zhang, Y., Jin, Y., Chevallier, J., \& Shen, B. (2016). The effect of corruption on carbon dioxide emissions in APEC countries: A panel quantile regression analysis. Technological Forecasting and Social Change, 112, 220-227. 


\section{Appendix: G4 anti-corruption indicators and their subparts}

\begin{tabular}{|c|c|c|c|}
\hline GRI code & Indicator & No & Subpart \\
\hline \multirow[t]{2}{*}{ G4-SO3 } & \multirow{2}{*}{$\begin{array}{l}\text { Total number and percentage of } \\
\text { operations assessed for risks } \\
\text { related to corruption and the } \\
\text { significant risks identified }\end{array}$} & 1 & $\begin{array}{l}\text { Report the total number and percentage of operations } \\
\text { assessed for risks related to corruption. }\end{array}$ \\
\hline & & 2 & $\begin{array}{l}\text { Report the significant risks related to corruption } \\
\text { identified through the risk assessment. }\end{array}$ \\
\hline \multirow[t]{5}{*}{ G4-SO4 } & \multirow[t]{5}{*}{$\begin{array}{l}\text { Communication and training on } \\
\text { anti-corruption policies and } \\
\text { procedures }\end{array}$} & 3 & $\begin{array}{l}\text { Report the total number and percentage of governance } \\
\text { body members that the organization's anticorruption } \\
\text { policies and procedures have been communicated to, } \\
\text { broken down by region. }\end{array}$ \\
\hline & & 4 & $\begin{array}{l}\text { Report the total number and percentage of employees } \\
\text { that the organization's anti-corruption policies and } \\
\text { procedures have been communicated to, broken down } \\
\text { by employee category and region. }\end{array}$ \\
\hline & & 5 & $\begin{array}{l}\text { Report the total number and percentage of business } \\
\text { partners that the organization's anti-corruption } \\
\text { policies and procedures have been communicated to, } \\
\text { broken down by type of business partner and region. }\end{array}$ \\
\hline & & 6 & $\begin{array}{l}\text { Report the total number and percentage of governance } \\
\text { body members that have received training on } \\
\text { anticorruption, } \\
\text { broken down by region. }\end{array}$ \\
\hline & & 7 & $\begin{array}{l}\text { Report the total number and percentage of employees } \\
\text { that have received training on anti-corruption, } \\
\text { broken down by employee category and region. }\end{array}$ \\
\hline \multirow[t]{4}{*}{ G4-SO5 } & \multirow[t]{4}{*}{$\begin{array}{l}\text { Confirmed incidents of } \\
\text { corruption and actions taken }\end{array}$} & 8 & $\begin{array}{l}\text { Report the total number and nature of confirmed } \\
\text { incidents of corruption. }\end{array}$ \\
\hline & & 9 & $\begin{array}{l}\text { Report the total number of confirmed incidents in } \\
\text { which employees were dismissed or disciplined for } \\
\text { corruption. }\end{array}$ \\
\hline & & 10 & $\begin{array}{l}\text { Report the total number of confirmed incidents when } \\
\text { contracts with business partners were terminated or } \\
\text { not renewed due to violations related to corruption. }\end{array}$ \\
\hline & & 11 & $\begin{array}{l}\text { Report public legal cases regarding corruption } \\
\text { brought against the organization or its employees } \\
\text { during } \\
\text { the reporting period and the outcomes of such cases. }\end{array}$ \\
\hline
\end{tabular}

Source: Global Reporting Initiative (2013) 
Table I: Sample employed for analysis

\begin{tabular}{lcc}
\hline \multicolumn{1}{c}{ Country } & Number & Percentage \\
\hline Indonesia & 41 & 35 \\
The Philippines & 13 & 11 \\
Thailand & 55 & 47 \\
Vietnam & 8 & 7 \\
\hline Total & $\mathbf{1 1 7}$ & $\mathbf{1 0 0}$ \\
\hline
\end{tabular}

Source: Original table

Table II: Measurement technique of the independent and control variables

\begin{tabular}{|c|c|c|c|}
\hline $\begin{array}{l}\text { Independent } \\
\text { variables }\end{array}$ & $\begin{array}{c}\text { Control } \\
\text { variables }\end{array}$ & Measurement & Type of data \\
\hline Government ownership & & $\begin{array}{l}1=\text { there is a proportion of government ownership } \\
0=\text { otherwise }\end{array}$ & Categorical \\
\hline $\begin{array}{l}\text { Government } \\
\text { dependence }\end{array}$ & & $\begin{array}{l}1=\text { there is a major government project, tender, } \\
\text { privatization project, or concession } \\
0=\text { otherwise }\end{array}$ & Categorical \\
\hline Foreign ownership & & $\begin{array}{l}1=\text { there is a proportion of foreign ownership } \\
0=\text { otherwise }\end{array}$ & Categorical \\
\hline International operations & & $\begin{aligned} 1= & \text { Yes-Have material foreign sales or a } \\
& \text { foreign subsidiary or a foreign branch } \\
& \text { office } \\
0= & \text { No material foreign sales, foreign subsidiaries } \\
& \text { or foreign branch offices }\end{aligned}$ & Categorical \\
\hline \multirow[t]{3}{*}{ UNGC membership } & & $\begin{array}{l}1=\text { the company is a member of UNGC } \\
0=\text { otherwise }\end{array}$ & Categorical \\
\hline & Industry type & $\begin{array}{l}1=\text { high corruption risk industry } \\
0=\text { low corruption risk industry }\end{array}$ & Categorical \\
\hline & Company size & Log of total assets & Continuous \\
\hline
\end{tabular}

Source: Original table 
Table III: Descriptive statistics of the independent and control variables

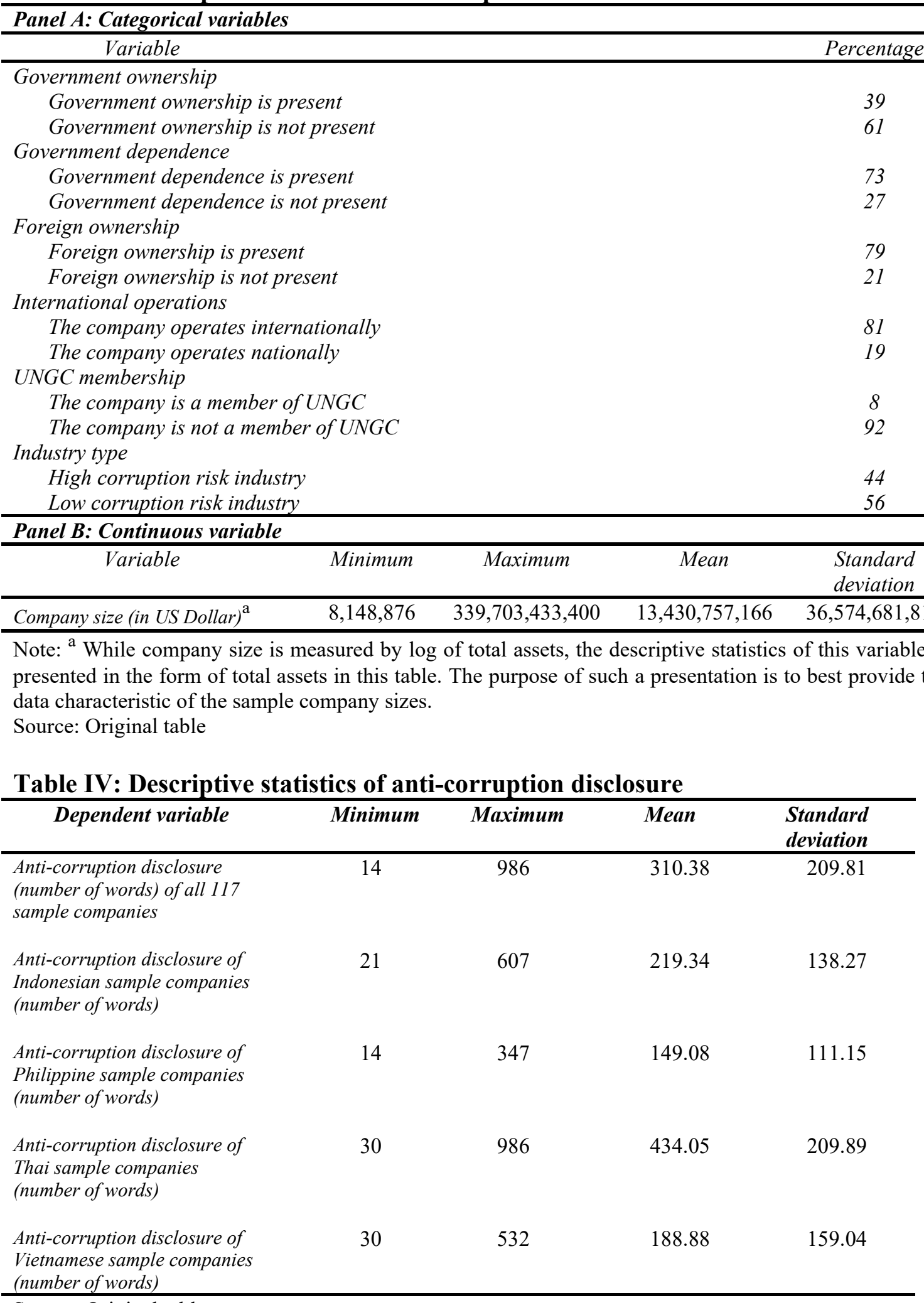

Source: Original table 
Table V: Results of multiple regression

\begin{tabular}{|c|c|c|c|}
\hline Variable & $\begin{array}{c}\text { Predicted } \\
\text { sign }\end{array}$ & Coefficient & $P$-value \\
\hline (Constant) & & 8.746 & 0.000 \\
\hline Government ownership & + & 0.091 & 0.941 \\
\hline Government dependence & + & 3.458 & $0.016 * *$ \\
\hline Foreign ownership & + & 3.768 & $0.009 * * *$ \\
\hline International operations & + & 2.181 & 0.140 \\
\hline UNGC membership & + & 1.145 & 0.599 \\
\hline Industry type (control variable) & + & 0.137 & 0.903 \\
\hline Company size (control variable) & + & 0.004284 & 0.520 \\
\hline \multicolumn{4}{|l|}{ Model summary } \\
\hline Adjusted R-Square & \multicolumn{3}{|c|}{0.077} \\
\hline Standard error of the estimate & \multicolumn{3}{|c|}{5.93833} \\
\hline Regression model (sig.) & \multicolumn{3}{|c|}{$0.027 * *$} \\
\hline
\end{tabular}

$* * *$ significant at $1 \%$ level; **significant at $5 \%$ level

Source: Original table

\section{Figure 1: Disclosure of anti-corruption}

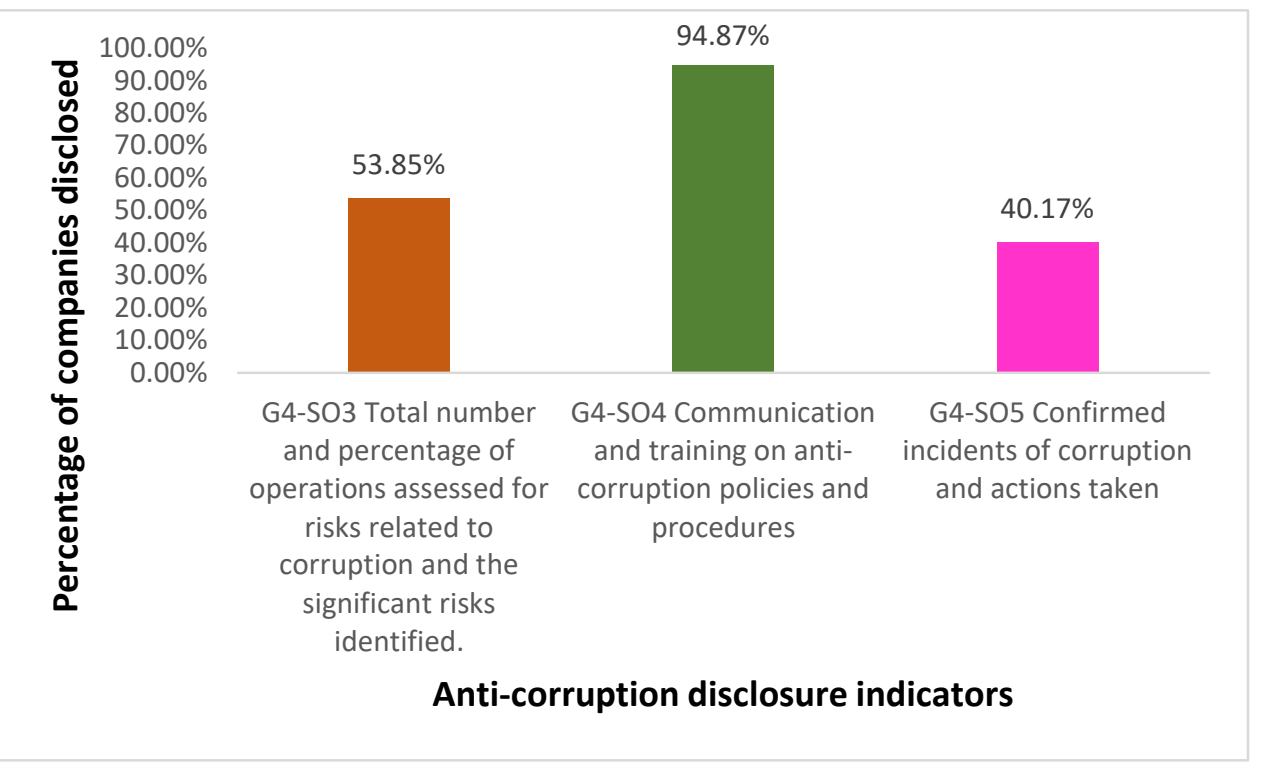

Source: Original figure 


\section{Note}

${ }^{1} \mathrm{UNGC}$ is a coalition initiated by the United Nations was launched in 2000 . The coalition has grown to about 2,900 signatory companies and 3,800 members in total. The coalition has ten principles that are focus on human right, labor, environment, and also anti-corruption (Organisation for Economic Co-operation and Development, 2008).

${ }^{2}$ In the context of this study, relevant stakeholders are those who potentially corrupt or those who potentially give opportunities to corrupt or to do other financial misconducts such as bribery. An amployee, for instance, is an internal stakeholder who potentially corrupts by illegally taking the company's money. A busines partner is an external stakeholder who may bribe some internal key people (or the other way around) so that a business conract can be extended.

${ }^{3}$ For brevity, the detailed results of the classical assumption tests are not presented in this paper. 